\title{
Analysis and Optimization of Shale Oil Refinery Wastewater Treatment Process
}

\author{
Fu Yuting ${ }^{1 *}$, Li Changbo ${ }^{1}$ Zhao Guozheng $^{1}$, Li Dongyu ${ }^{1}$, Yang Jiatong ${ }^{1}$ and Sun Zikai ${ }^{1}$ \\ ${ }^{1}$ School of Environmental and Safety Engineering, Liaoning Petrochemical University, Fushun, Liaoning, 113000, China
}

\begin{abstract}
Shale oil refinery wastewater was a kind of industrial wastewater with many types of organic matter and complex water quality. It contains a large amount of pollutants such as phenols, ammonia and oil, which is extremely harmful to the environment. Due to the increasingly stringent national discharge standards, it was difficult to treat wastewater up to standard with only one method, and multiple methods are needed to jointly treat wastewater. In this paper, the process of shale oil refinery wastewater treatment system was modified, and the "SDN+Advanced Oxidation+MBR" process was proposed to treat wastewater.
\end{abstract}

\section{Introduction}

Oil shale is a brownish-black sedimentary rock that coexists with coal and is located on the upper part of the coal seam. In recent years, oil prices have risen, and oil shale production has increased. Oil shale is a brownishblack sedimentary rock that coexists with coal and is located on the upper part of the coal seam. The oil shale reserves in the United States amount to more than 300 billion tons, accounting for $70 \%$ of the world's shale[1]. The raw material for refining in the dry distillation furnace is oil shale. The oil shale is crushed and screened by the original ore device, and transported by conveyor belt to the feed bin above the dry distillation furnace. The oil shale enters the dry distillation furnace and is heated to a certain temperature. The temperature and the shale oil contained in it were released into the form of gas. After the gas rises, it is transported to the washing tower through the gas manifold of the dry distillation furnace, and is washed and washed by the cooling water of the washing tower, and then cooled into condensed water containing shale oil. After the condensed water settles, separates, and settles, shale crude oil is separated. The dry distillation gas from which heavy oil and solid matter is removed passes through the compressor, and then enters the dry distillation furnace to provide heat to the shale after being heated. Part of the oil shale after dry distillation is recycled as a heat carrier, and shale ash is used for comprehensive utilization of cement, ceramsite and block.

\section{The Original Treatment Progress}

The existing wastewater treatment facilities of the refinery include thick water tanks and homogenizing tanks, and only preliminary oil separation and sedimentation treatments are carried out on the production wastewater. The process is as follows: the wastewater from the production workshop is collected to the thick pool, heated in the pool and left to stand for oilwater separation, the slick oil is removed regularly, the wastewater is lifted to the homogenization pool by the pump, and the wastewater is placed in 3 homogenization pools in turn 4 After $6 \mathrm{~h}$, the supernatant is returned to the production system, and the sludge is removed regularly. The design of this process is simple, and the treatment effect of shale oil refinery wastewater with high pollutant content is poor[2], so this process needs to be improved. The original treatment process needs to be improved to treat the refractory pollutants such as phenols and ketones in the wastewater to meet the discharge standards[3].

\section{Process Optimization}

As shown in Fig. 1, it can be seen that the overall process flow of this project is mainly composed of the pretreatment section[4], biological treatment section[5], advanced treatment section and sludge treatment section.

\subsection{Pretreatment Section}

The pretreatment section is composed of a diagonal water outlet adjustment tank, an oil separation sedimentation tank, an air flotation tank, an ammonia distillation tower, and a neutralization adjustment tank. When the homogenization pool is drained under selfpressure, with the change of the liquid level of the pool, the water quality and quantity of wastewater fluctuate greatly. In order to balance the water quality and quantity, the wastewater treatment station sets up a diagonal water outlet regulating the pool.

The oil trap sedimentation tank is used to separate sludge and oily substances, with a total design capacity of $3000 \mathrm{~m}^{3} / \mathrm{d}$ and a residence time of $2 \mathrm{~h}$. Add coagulant and flocculant to the inlet pipe mixer of the oil

* Corresponding author: Inpulcb@126.com 
separation sedimentation tank to improve the removal effect of sludge and oil. The sludge precipitated in the oil trap sedimentation tank is discharged to the sludge dewatering system through an oil sludge pump. A steam heating coil is installed in the sedimentation area of the oil trap sedimentation tank, and heating under low temperature conditions is beneficial for sludge discharge. The oil separated in the oil-water separator is regularly transported to recycling. Air flotation equipment can further reduce the content of floating oil and emulsified oil in wastewater, and can also remove part of the suspended oil in wastewater.

The air flotation method is a method to make the impurity particles rise to the surface of the water by buoyancy to separate solid and liquid. Due to the high oil content in wastewater, in order to ensure the oil removal effect, this project adopts partial pressurized dissolved air flotation equipment with better treatment effect. The main design parameters of air flotation equipment: processing capacity $130 \mathrm{~m}^{3} / \mathrm{h}$, residence time $30 \mathrm{~min}$, surface load rate $4.1 \mathrm{~m}^{3} /\left(\mathrm{m}^{2} \cdot \mathrm{h}\right)$, reflux ratio $30 \%$, dissolved air water volume $40 \mathrm{~m}^{3} / \mathrm{h}$.

The effluent treated by the air flotation device is sent by the lift pump to the ammonia distillation tower for ammonia distillation and denitrification, and at the same time, the concentrated ammonia water is recovered. The wastewater condensed during the cooling process of shale refining products has high ammonia content. It is advisable to use ammonia distillation equipment to first carry out ammonia recovery treatment, and then enter the biochemical system for treatment to reduce the difficulty of wastewater treatment [6]. The raw material wastewater after degreasing treatment is about $35^{\circ} \mathrm{C}$. After adding alkali, it will reach about $90^{\circ} \mathrm{C}$ after being preheated by the preheater. It enters the upper part of the ammonia distillation tower. The operating pressure of the ammonia distillation tower is $0.015 \mathrm{MPa}$, and the tower uses $0.3 \mathrm{MPa}$. The saturated steam provides the heat source for stripping and distilling the free ammonia in the wastewater. The liquid at the bottom of the tower is heated to boiling by steam. The concentration of ammonia from bottom to top increases step by step. The ammonia and water vapor exiting the ammonia tower are in the tower. After the top rectification, the ammonia water with a concentration of $15-18 \%$ is sent to the ammonia water collection tank. After the ammonia distillation tower recovers from ammonia, the discharged waste water flows into the neutralization adjustment tank under the action of gravity. The $\mathrm{pH}$ of the effluent from the ammonia distillation tower is too high and cannot directly enter the biochemical system, so acid adjustment is required.

\subsection{Biological treatment section}

The biological treatment section is composed of a SDN tank and a secondary sedimentation tank. Both the SDN process and the conventional $\mathrm{A} / \mathrm{O}$ [7] process are composed of two parts: anoxic tank (A tank) and aerobic tank (O tank). The anoxic tank is placed at the front end. The significant difference between the $\mathrm{A} / \mathrm{O}$ process and the SDN process is that the SDN process makes full use of the conventional $\mathrm{A} / \mathrm{O}$ denitrification and denitrification performance, and strengthens its anoxic and aerobic performance. The anoxic tank has both hydrolytic acidification and denitrification functions, and has the functions of degrading organic pollutants and removing nitrogen. In the SDN process, the dissolved oxygen in the anoxic tank is controlled below $0.5 \mathrm{mg} / \mathrm{L}$, and the dissolved oxygen in the aerobic tank is about 3 $\mathrm{mg} / \mathrm{L}$. In the SDN process system, the mixed liquid reflux ratio is $200-400 \%$, and the mixed liquid reflux ratio can be adjusted appropriately according to the size of the nitrate nitrogen in the wastewater to make the denitrification and denitrification more thorough. When the influent concentration increases, the influent concentration is diluted by increasing the reflux ratio, thereby effectively buffering the pollutant impact load of the system, making the system operation more stable and the operation control simpler. To supplement the biological nutrient $\mathrm{P}$, phosphate $\left(\mathrm{K}_{2} \mathrm{HPO}_{4}\right)$ is added to the front of the SDN pool, and the dosage is BOD5:P=100:1. Simple functional partitioning has also been done in the $\mathrm{O}$ pool, and the $\mathrm{O}$ pool operation control is made more flexible and more powerful by improving the aerator layout of the $\mathrm{O}$ pool. The aerobic tank uses a microporous aerator as a means of oxygenation, which is then lifted to the SDN tank by a pump. 


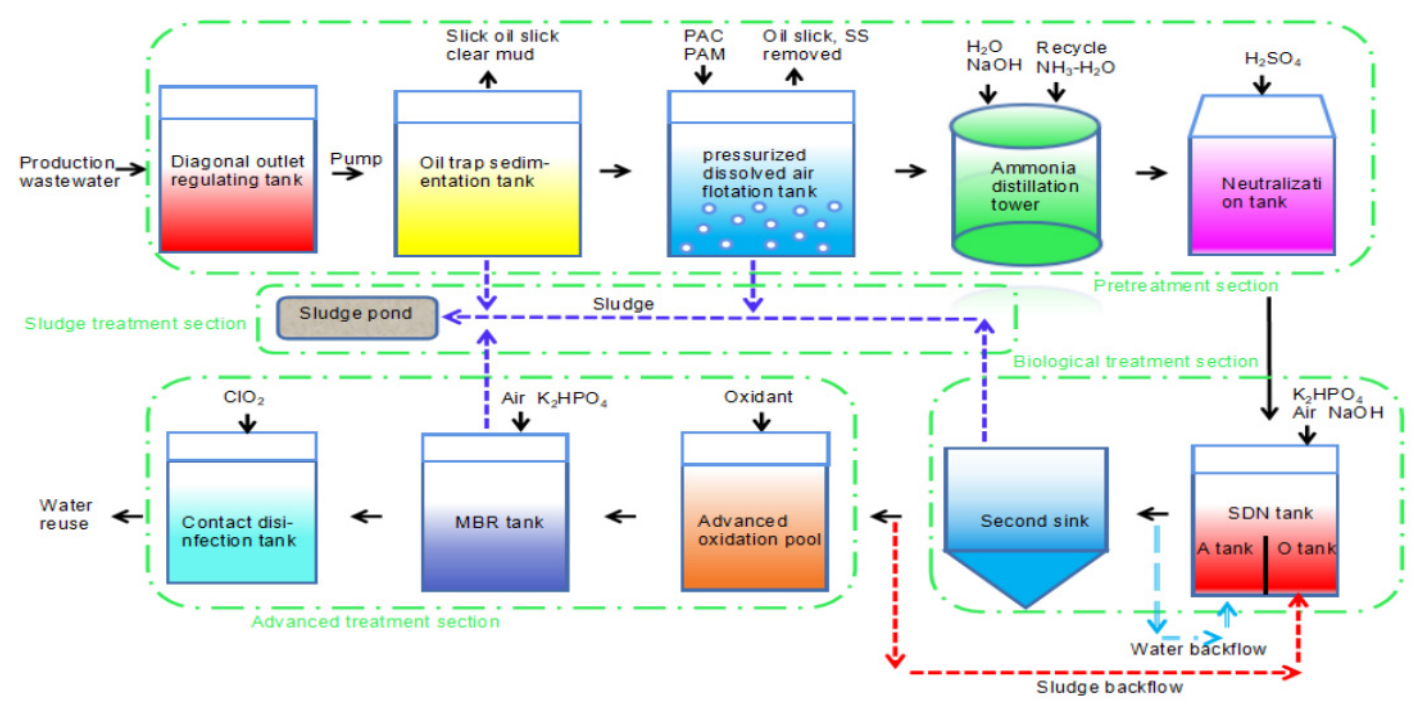

Fig. 1. Optimization of shale oil refinery wastewater treatment process

The secondary sedimentation tank adopts a central water-inlet radial flow sedimentation tank. Part of the sludge separated in the secondary settling tank is returned to the SDN tank to maintain the concentration of activated sludge in the biochemical system and ensure the normal operation of the biochemical system; the other part of the remaining sludge is pumped into the sludge tank by the sludge pump.

\subsection{Advanced treatment section}

The advanced treatment section is composed of an advanced oxidation tank, MBR tank and contact disinfection tank. Since there are many difficult-todegradable substances in wastewater and poor biochemical properties, organic substances that cannot be effectively removed in the front-end biochemical treatment can be decomposed by the ozone catalytic oxidation method[8], which is beneficial to the subsequent biochemical treatment. After the wastewater has undergone advanced oxidation to improve its biodegradability, the MBR[9-10] method is used to further biochemically degrade and remove organic matter and ammonia nitrogen in the wastewater to meet the reuse standard. The bioreactor can maintain a high concentration of microorganisms, usually MLSS is 8$10 \mathrm{~g} / \mathrm{L}$, up to $12-15 \mathrm{~g} / \mathrm{L}$, while the MLSS in the conventional activated sludge aeration tank is $3-5 \mathrm{~g} / \mathrm{L}$. In order to supplement the biological nutrient P, K2HPO4 is usually added at the front end of the MBR pool, and the dosage is $\mathrm{BOD}_{5}: \mathrm{P}=100: 1$. The MBR residence time is $3 \mathrm{~h}$.

The effluent from the MBR tank is sucked by the pump into the contact disinfection tank. In the disinfection tank, $\mathrm{ClO}_{2}$ is added to disinfect the effluent to meet the requirements of recycled water quality. The reaction time of the contact disinfection tank is 30 minutes, and the effective chlorine dosage is $5-8 \mathrm{mg} / \mathrm{L}$.

\subsection{Sludge treatment section}

The sludge treatment section consists of a sludge pump room, sludge dewatering equipment and storage equipment. The system sludge comes from four parts: oil sludge in the oil separation sedimentation tank, scum in the air flotation tank, residual sludge in the secondary sedimentation tank and MBR residual sludge. The sludge is lifted by the pump into the sludge storage tank, and the mixed sludge is pumped into the centrifugal dewatering machine for sludge dewatering, and the dewatered mud cake is regularly transported out.

Table 1. Functions of each unit of sewage treatment

\begin{tabular}{|c|c|c|}
\hline $\begin{array}{c}\text { Serial } \\
\text { Number }\end{array}$ & Name & Features \\
\hline 1 & $\begin{array}{c}\text { Diagonal } \\
\text { outlet } \\
\text { regulating } \\
\text { tank }\end{array}$ & $\begin{array}{c}\text { Balance water quantity } \\
\text { and quality }\end{array}$ \\
\hline 2 & $\begin{array}{c}\text { Oil trap } \\
\text { sedimentation } \\
\text { tank }\end{array}$ & $\begin{array}{c}\text { Initially remove most of } \\
\text { the suspended oil }\end{array}$ \\
\hline 3 & $\begin{array}{c}\text { Floatation } \\
\text { Pool }\end{array}$ & $\begin{array}{c}\text { Remove the remaining } \\
\text { small amount of slick oil, } \\
\text { various impurities and } \\
\text { the suspended matter } \\
\text { generated by the reaction }\end{array}$ \\
\hline 4 & $\begin{array}{c}\text { Ammonia } \\
\text { distillation } \\
\text { tower }\end{array}$ & $\begin{array}{c}\text { Removal of ammonia } \\
\text { nitrogen and other light } \\
\text { components in } \\
\text { wastewater }\end{array}$ \\
\hline 5 & $\begin{array}{c}\text { Neutralization } \\
\text { tank }\end{array}$ & Adjust pH \\
\hline
\end{tabular}




\begin{tabular}{|c|c|c|}
\hline 6 & SDN pool & $\begin{array}{l}\text { Degradation of organic } \\
\text { pollutants and } \\
\text { denitrification }\end{array}$ \\
\hline 7 & Second sink & $\begin{array}{l}\text { Carry out mud-water } \\
\text { separation }\end{array}$ \\
\hline 8 & $\begin{array}{c}\text { Advanced } \\
\text { oxidation pool }\end{array}$ & $\begin{array}{c}\text { Pollutants that are } \\
\text { difficult to degrade in } \\
\text { oxidized wastewater, } \\
\text { such as phenols, ketones } \\
\text { and aldehydes }\end{array}$ \\
\hline 9 & MBR pool & $\begin{array}{c}\text { Degrade organic matter } \\
\text { and ammonia nitrogen in } \\
\text { wastewater to meet the } \\
\text { standard of reuse }\end{array}$ \\
\hline 10 & $\begin{array}{c}\text { Contact } \\
\text { disinfection } \\
\text { tank }\end{array}$ & $\begin{array}{l}\text { Oxidation to remove } \\
\text { cyanide, sulfide, volatile } \\
\text { phenol and ammonia } \\
\text { nitrogen components in } \\
\text { wastewater }\end{array}$ \\
\hline 11 & $\begin{array}{l}\text { Sludge } \\
\text { treatment } \\
\text { section }\end{array}$ & $\begin{array}{c}\text { Extruding and } \\
\text { dewatering the remaining } \\
\text { sludge to achieve the } \\
\text { purpose of volume } \\
\text { reduction and weight } \\
\text { reduction }\end{array}$ \\
\hline
\end{tabular}

\section{Conclusion}

The "SDN+Advanced Oxidation+MBR" process is used to treat shale oil refining wastewater, which has the characteristics of good effluent quality, stable operation, high processing load and low mud production. This process is more suitable for the treatment of shale oil refinery wastewater. The combined use of advanced oxidation and biochemical methods can remove phenols and other refractory substances in the wastewater.

\section{Acknowledgments}

This paper was supposed by the key research project of the Department of Education of Liaoning Province L(2020003) and the project of the Department of Education of Liaoning Province(L2020020).

\section{References}

1. J. R. Dyni, Geology and Resources of some World Oil Deposits. J. Oil Shale., 20, 193-252 (2003)

2. J. Gersten, V. Fainberg and A. Garbar, Utilization of waste polymers through one-stage low-temperature pyrolysis of oil shale. J. Fuel., 78, 987-990 (1999)

3. A. Kahru and I. Pollumaa, Environmental hazard of the waste streams of Estonian oil shale industry an ecotoxioological review. J. Oil Shale., 23, 53-93 (2006)

4. M. -F. Alexandre and F. -V. Nascimento, Ammonia stripping, activated carbon adsorption and anaerobic biological oxidation as process combination for the treatment of oil shale wastewater. J. Environ. Technol., 37, 2608-2616 (2016)

5. N. Matouq, O. Alayed and Z. Alanber, Wastewater treatment resulting from an oil shale retorting at high frequency ultrasound waves with a chemical elemental analysis. J. Energ. Source., 32, 1878-1884 (2010)

6. K. Klein, E. Kattel and A. Goi, Combined treatment of pyrogenic wastewater from oil shale retorting. J. Oil Shale., 34, 82-96 (2017)

7. B. -H. Zeeman, S. -A. Luostarinen, Treatment technologies for petroleum refinery effluents: $A$ review. J. Process. Saf. Environ., 89, 95-105(2011)

8. L. Zhao, W. Ma and J. Ma, Characteristic mechanism of ceramic honeycomb catalytic ozonation enhanced by ultrasound with triple frequencies for the degradation of nitrobenzene in aqueous solution. J. Ultrason. Sonochem., 21, 104-112 (2014)

9. J. Sanna, G. Adewale and W. -H. Shadi, Recent improvements in oily wastewater treatment: Progress, challenges, and future opportunities. J. J. Environ. Sci., 37, 15-30 (2015)

10. B. Mitra, R. -M. Mohammad and H. Mostafa, Petrochemical wastewater treatment and reuse by MBR: A pilot study for ethylene oxide/ethylene glycol and olefin units. J. J. Ind. Eng. Chem., 25, 265-271 (2015) 